\title{
SE TUNNE, KUN OPETTAA VERKKOKURSSIA MEEMEISTÄ JA TEKIJÄNOIKEUKSISTA
}

Mitä tekijänoikeuskysymyksiä liittyy internetin meemeihin? Korkeakouluopinnoissa harjoitellaan teksteihin viittaamista, mutta kuvien tekijyys on usein vaikea asia. Helsingin yliopiston kirjasto järjesti verkkokurssin meemien ja valokuvien tekijänoikeuskysymyksistä. Kurssin suosio ylitti odotukset ja palaute oli erinomaista. Mitä opiskelijat oppivat kuyamateriaa-/ lien tekijänoikeuksista meemien kautta? Millaisia oivalluksia kurssi añ̂toi hyvistä verkkopedagogiikan käytänteistä?

M onilukutaitoisuuden vaatimus on arkipäivää myös korkeakoulujen kampuksilla. Meemeissä käytetyistä kuvista on usein hankala tietää, mistä kuvat ovat peräisin, miten niitä muokataan ja miten ne leviävät.

Yliopisto-opiskelija hyödyntää kuvia opinnoissaan esimerkiksi laatiessaan PowerPoint-esitystä ryhmätyötä varten. Kuvalla on tekijä ja toisinaan kuvissa esiintyy myös tunnistettavia henkilöitä. Kuvien käyttämiseen liittyy näin ollen tekijänoikeuksiin ja tietosuojaan liittyviä kysymyksiä.

Helsingin yliopiston kirjasto järjesti lukuvuonna 2019-2020 Meemin ja kuvan tekijänoikeus -verkkokurssin, joka keskittyi meemien ja valokuvien käyttöön liittyviin tekijänoikeuskysymyksiin. Kurssi oli suunnattu pääasiassa Helsingin yliopiston perustutkinto-opiskelijoille.

\section{Verkkokurssin lähtökohdat}

Kurssin tavoitteena oli, että opiskelija oppii tunnistamaan internetin meemikulttuuriin piirteitä, osaa soveltaa Creative Commons -lisenssejä sekä ymmärtää näihin ilmiöihin liittyviä tekijänoikeudellisia rajoituksia. Kurssin osallistujat harjoittelivat kuvien etsimistä kuvapankeista, kuvien käyttöehtojen tulkitsemista ja käänteiden kuvahaun työkalujen käyttämistä.
Opettajana vastasin kurssin pedagogisesta suunnittelusta ja oppimateriaalin kokoamisesta. Käytin osittain valmista materiaalia, mutta tuotin kurssia varten myös uutta oppimateriaalia. Opettajana jouduin tasapainottelemaan sen kanssa, miten paljon kurssilla on tekijänoikeuksien teoriaa ja miten paljon käytännön soveltamista. Halusin, että kurssin painopiste oli enemmän käytännön tasolla, jotta opiskelijat saisivat taitoja tekijänoikeuksien soveltamiseen verkossa kuvia käsitellessään.

En ole itse juristi, mutta onneksi tekijänoikeuksiin liittyvää asiantuntemusta löytyi kampukselta oikeustieteellisen tiedekunnan käytäviltä. Rakensimme yhdessä tutkija Anette Alén-Savikon haastattelutyyppisen opetusvideon, joka on aiheesta kiinnostuneiden käytettävissä CC BY-NC-ND -lisenssillä.

Valitsin kurssin opetusalustaksi Helsingin yliopiston Moodlen. Opiskelijat eivät saaneet kurssista opintopisteitä, vaan ainoastaan suoritusmerkinnän rekisteriin. Verkkokurssin osallistujamäärä ylitti villeimmätkin odotukset: Moodle-alueella kirjautui yli ıoo opiskelijaa useasta tiedekunnasta ja eri opintojen vaiheista. Pääsin käyttämään toden teolla opetuksen periaatteita ja välineitä, jotka soveltuivat

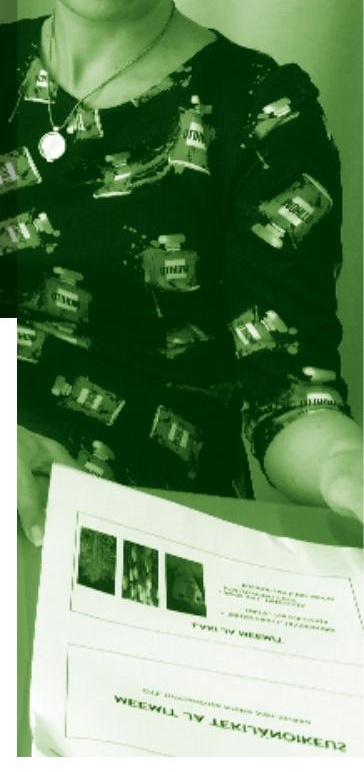


suurelle ryhmäkoolle. Kurssille osallistui perustutkinto-opiskelijoiden lisäksi myös kaksi yliopiston henkilökuntaan kuuluvaa henkilöä.

\section{Miten rakentaa vuorovaikutus- ta verkkokurssilla?}

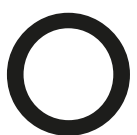

pintopisteettömän verkkokurssin haasteena oli sitouttaa opiskelijat kurssiin.

Kurssin rakenteen ja opettajan läsnäolon täytyi motivoida ja tukea tehtävien suorittamista. Käytin etukäteen erityisesti aikaa siihen, että paloittelin kurssin sisällöt järkevän mittaisiksi kokonaisuuksiksi ja suunnittelin oppimistavoitteita tukevat oppimistehtävät. Videomuotoisella kurssin esittelyvideolla pyrin helpottamaan opiskelijoiden perehtymistä kurssin suoritustapaan ja tavoitteisiin.

Verkko-opetuksessa on hyväksyttävä se, että kaikesta ohjeiden hiomisesta huolimatta osa opiskelijoista ei ymmärrä ohjeita tai ymmärtää ne väärin. Pidin erityisen tärkeänä kertoa, miten ja milloin olen opiskelijoiden tavoitettavissa. Oma virtuaalinen läsnäoloni ei veny yhtä laajaksi kuin opiskelijoiden mahdollisuus suorittaa kurssia: siinä missä lähettelin viestejä ja seurasin verkkokeskustelua työaikana, opiskelijat saattoivat suorittaa tehtäviä ja lähettää viestejä mihin vuorokaudenaikaan hyvänsä.

\section{Tarkistuspisteet aikataulun tukena}

Rakensin opetusaikatauluun tietyt tarkistuspisteet, jolloin kävin läpi saapuneita tehtäviä ja lähetin tarvittaessa opiskelijoille sähköpostia. Tarkistuspisteissä poimin ne opiskelijat, joiden arvelin hyötyvän sähköpostimuotoisista muistutuksista tai ohjeista. Opiskelijalta saattoi esimerkiksi puuttua juuri ratkaiseva tehtävä hieman ennen deadlinea, joten muistutin näistä opiskelijoista koostuvaa ryhmää viestilläni. Kohdennettu sähköpostiviestintä osoittautui erittäin tehokkaaksi viestintäkeinoksi.

Lähestyin kaikkia osallistujia kurssin aikana noin kerran viikossa Moodle-alueen opettajan palstalla yleisillä viesteillä. Yleiset viestit olivat esimerkiksi kertaavia ja täydentäviä ohjeistuksia, muistutuksia deadlineista tai yhteispalautetta suoritetuista tehtävistä. Yleisissä viesteissä pidin tärkeänä säännöllisyyttä, jotta opettajan läsnäolo olisi näkynyt kurssilla.

Kaikesta opettajan vaivannäöstä huolimatta osa osallistujista kävi verkkokurssilla vain kääntymässä. Kaikki kurssille ilmoittautuneet eivät tosiasiassa suorittaneet kurssia loppuun. Opettajan on kuitenkin aina tärkeää muistaa, että opiskelija voi oppia kurssilla uusia asioita, vaikka ei suorittaisikaan kurssia loppuun.

\section{Mitä kurssista jäi käteen?}

Lopulta 50 opiskelijaa suoritti kurssin alusta loppuun, mikä tarkoitti kaikkien vaadittujen tehtävien palauttamista Moodle-alueelle. Alun perin suunnittelin kurssia 30 opiskelijalle, joten tässä suhteessa tavoite to-

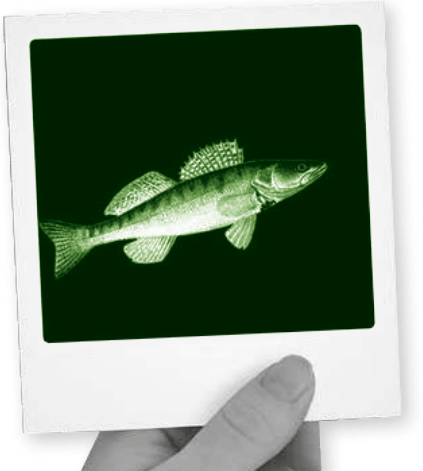


teutui enemmän kuin hyvin.

Kurssin suunnittelussa oli antoisaa se, että löysin yhteistyötahoja myös Helsingin yliopiston omasta tutkijayhteisöstä. Anette Alén-Savikon kanssa toteutettu video jää kurssin jälkeen verkkoon katsottavaksi, joten tehty työ ulottuu kurssia laajemmalle aikavälille. Kurssi osallistui myös Helsingin yliopiston Mixed Reality Hubin verkko- ja virtuaalitodellisuuskursseja koskevaan tutkimukseen.

Opiskelijapalautteen perusteella kurssi sai arvosanaksi yli 8 (asteikolla o-Io), mikä olisi miltä tahansa kurssilta onnistunut saalis. Opiskelijat raportoivat oppineensa esimerkiksi erilaisten lisenssien hyödyntämistä ja kokeneensa saaneensa varmuutta kuvien käyttöön.

Poimintoja opiskelijapalautteesta (vastauksia kysymykseen "Mitä opin kurssilla?”)

"Opin paljon kuvien käytöstä ja eri lisensseistä. Tämä oli erittäin tärkeää tietoa pro gradu -tutkielmaani varten. Lisäksi opin myös Googlen käänteisen kuvahaun, joka oli erittäin helppo käyttää ja mainio työkalu."

"Paljon tekijänoikeuksista ja lainsäädännöstä, tulin itsevarmemmaksi kuvien lainaajaksi ja opin uusia hakutapoja."

"Opin sitä mitä odotinkin eli meemien ja kuvien tekijänoikeuksia sekä kuvien käytössä huomioitavia asioita. Kurssi oli hyödyllinen!"

"Tekijänoikeuksista ja linsesseistä luvallisen käytön tiedot. Varmistui myös aiempi epäilyni siitä, että todella suuri osa internetissä jaettavasta kuvamateriaalista on laittomasti jaettua."
"Opin Cc-lisenssien ja kuvapankkien hyödyntämisestä. Tekijänoikeudesta vapaata materiaalia, jota voisi hyödyntää esimerkiksi esitelmissä, on yllättävän paljon."

Opettajan kannalta oli haastavaa laatia kaikille sopivia tehtäviä. Palautteesta näkyy, että osa opiskelijoista piti kurssia laajana, osa liian suppeana. Useiden opiskelijoiden palautteessa nousi esiin, että he olisivat toivoneet kurssista opintopisteitä. Kurssille osallistui myös oikeustieteen opiskelijoita, vaikka kurssia ei oltukaan räätälöity erikseen heille ja kurssin oli tarkoitus sopia kaikkien tiedekuntien opiskelijoille.

Opiskelijapalautteessa korostui, että kurssin osallistujat kokivat saaneensa lisää itsevarmuutta kohtalaisen hankalien tekijänoikeusasioiden hahmottamiseen. Opiskelijat ovat kiinnostuneita visuaalisten aineistojen tekijänoikeuksista ja heille kurssi oli tervetullut. Yllätyin, että moni opiskelija ei ollut aikaisemmin käyttänyt käänteisen kuvahaun työkaluja. Ei-tekstipohjaisen aineiston hakemiseen soveltuvat työkalut tulevat lähivuosina vain yleistymään, joten niiden käytön harjoittelulle on tilausta.

Opettaja ei verkko-opetuksessa pääse siitä, mistä aita on matalin. Laadukkaiden opetusmateriaalien tekeminen vie aikaa. Kokeilu osoitti, että aihe kiinnostaa. Tekijänoikeuksien opetuksessakin voi rohkeasti tarttua ajankohtaisiin ilmiöihin, joiden kautta opettaja ja opiskelijat voivat yhdessä lähteä rakentamaan yhteistä ymmärrystä.

\section{Kirjoittaja}

Minna Suikka

Helsingin yliopiston kirjasto, minna.suikka@helsinki.fi

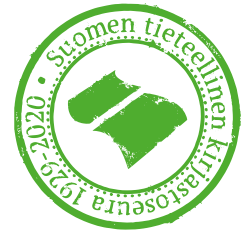

